\title{
El extraño viaje de Ibn al-Jațīb por los agitados llanos de Tāmasnā. Estudio y traducción de la riḥla
}

\section{The strange journey of Ibn al-Khatīib through the turbulent plains of Tāmasnā. Study and translation of the rihla}

\author{
Laila M. JREIS NAVARRO \\ Universidad de Granada \\ laylajreis@gmail.com
}

Recibido: 16 de enero de 2015

Aceptado: 15 de junio de 2015

\section{RESUMEN}

En el invierno de 1362 el exiliado visir granadino Lisān al-Dīn Ibn al-Jațīb realizaba un viaje por la región magrebí de Tāmasnā en plena guerra civil. Mientras su destronado monarca nazarí luchaba en tierras andalusíes con apoyo castellano para recuperar el trono de Granada, él atravesaba regiones tribales al encuentro de los grandes agentes del conflicto meriní. El relato de su viaje, escrito en prosa rimada a modo de epístola literaria, figura en su obra Nufādat al-ŷirāb, considerada sus memorias de exilio. Este artículo aborda el estudio del peculiar contexto de esta riḥla, ofrece una hipótesis viable a las motivaciones de su autor y traduce el inacabado texto de esta acompañado de un estudio filológico que permite saborear el exquisito y característico estilo jatibiano.

Palabras clave: Ibn al-Jațīb, Rihla, Relato de viaje, Exilio, Meriníes, Nazaríes, Traducción, Literatura andalusí.

\begin{abstract}
During the winter of 1362 the exiled Granadian vizier Lisān al-Dīn Ibn al-Khațīb was on a journey through the Maghrebian region of Tāmasnā in the midst of civil war. While his dethroned Nasrid monarch was fighting in Andalusian lands with Castilian support to regain the throne of Granada, he was crossing tribal regions to meet the great players of the Merinid conflict. The story of his journey, writ-

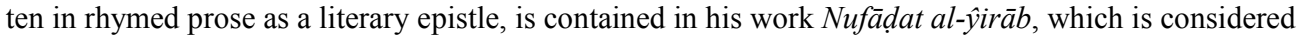
his memories of exile. This paper analyzes the unique context of this rihla, offers a viable hypothesis to the motivations of the author and translates the unfinished text accompanied by a philological study that allows us to savor the exquisite and distinctive Khatibian style.
\end{abstract}

Keywords: Ibn al-Khațīb, Riḥla, Travel narrative, Exile, Merinids, Nasrids, Translation, Andalusian literature. 
El periodo más esplendoroso de la Granada nazarí que tuvo lugar durante el truncado reinado de Muhammad V (1354-1359 y 1362-1391) ${ }^{1}$ estuvo marcado por el derrocamiento de este y su exilio al Magreb meriní en el contexto de una agitada situación peninsular. Varios agentes intervinieron en las luchas por la hegemonía del Estrecho. Castellanos, aragoneses, granadinos y magrebíes jugaban en un esquema de alianzas variable marcado por las luchas dinásticas y el intervencionismo directo e indirecto de unos y otros en la política de los reinos rivales.

El derrocamiento de Muhammad V marcó un cambio en su política exterior que caracterizará su segundo reinado, un cambio hacia la independencia del norte de África que acabará con el tiempo dictando los últimos años del Islam peninsular medieval. El momentáneo poder que permitió a Granada tal alarde no fue más que el reflejo de una coyuntura pasajera marcada principalmente por las luchas dinásticas de Castilla.

Para acercarnos algo más al significado de los años cruciales entre 1359 y 1362 que marcaron un antes y un después en la historia de la Granada nazarí, no podemos más que asomarnos a la producción del gran literato y político que gracias a su ingente y variada obra nos ha conservado como testigo presencial el cuadro más completo de su tiempo. El resonado visir granadino Lisān al-Dīn Ibn al-Jațīb no solo fue uno de los más poderosos agentes del poder nazarí durante este reinado, algo propio de los visires en tiempos de inestabilidad, sino que tuvo la habilidad y certeza de transmitir su conocimiento y experiencia por escrito arrojando luz a tiempos de oscuridad.

Ibn al-Jațīb, al igual que su monarca, tuvo que sufrir las consecuencias del derrocamiento. Encarcelado y liberado por intervención meriní, logra escapar con

\footnotetext{
${ }^{1}$ Para conocer los acontecimientos más destacados de su reinado y de su exitosa política exterior, ver: VIDAL CASTRO, Francisco, "Historia política", en Historia de España Menéndez Pidal (Tomo VIII-III): El Reino Nazarí de Granada (1232-1492). Política, Instituciones, Espacios y Economía, M ${ }^{a}$ J. Viguera Molins (coord.) (2000), 133-41. Para una perspectiva más amplia del contexto general que encuadra el momento histórico referido se remite a esta selección de estudios destacados: Al'ABBĀDĪ, Ahmmad Mujtār, Dirāsāt fì tārīj al-Magrib wa-l-Andalus, Beirut 1978; KABLY, Mohamed, Société, pouvoir et religión au Maroc à la fin du Moyen-Age, París 1986; GARCÍA ARENAL, Mercedes y VIGUERA, Ma Jesús (Eds.), Relaciones de la Península Ibérica con el Magreb (siglos XIIIXVI), Madrid 1988; MANZANO, Miguel Ángel, La intervencón de los benimerines en la Península Ibérica. Madrid 1992; VIGUERA, "Ibn al-Jațīb visita el monte de los Hintāta" en Homenaje al profesor José María Fórneas Besteiro, Concepción Castillo, Inmaculada Cortés et alii (eds.) (1995) vol. I, 644-591; AL-MANŪNĪ Moḥammad, Waraqāt 'an hậ̣ārat al-marīniyyīn, Casablanca 1996; CORTÉS, Inmaculada (coord.), Triángulo de al-Andalus, Granada 2003; BENEITO, Pablo y ROLDÁN, Fatima (eds.), Al-Andalus y el Norte de África: relaciones e influencias, Sevilla 2004; VIGUERA (coord.), Ibn Jaldún, el Mediterráneo en el siglo XIV, Sevilla 2006; MORAL, Celia del, y VELÁZQUEZ BASANTA, Fernando (eds.), Ibn al-Jațīb y su tiempo, Granada 2012; RODRÍGUEZ, M ${ }^{\mathrm{a}}$ Dolores, PELÁEZ, Antonio y BOLOIX, Bárbara (eds.), Saber y poder en al-Andalus. Ibn al-Jațīb (siglo XIV), Córdoba 2014; y BENNISON, Amira K. (ed.), The articulation of power in medieval Iberia and the Maghrib, Oxford 2014.
} 
Muḥammad V a Fez bajo el auspicio del sultán magrebí Abū Sālim y el apoyo de su amigo y maestro Ibn Marzūq, que tiempo atrás se habían refugiado en Granada. Acoger a los disidentes del gobierno de un reino era una práctica común que garantizaba una intervención directa en la política del adversario en tiempos de debilidad. De esta experiencia de exilio y del contexto histórico que la propició se hace eco el visir en numerosas obras, pero solo una fue su "Sacudida de alforjas para entretener el exilio". A su vuelta a Granada, tras la recuperación de Muhammad V del trono nazarí, Ibn alJațīb concluirá su obra más íntima que designará como kitāb al-rihhla (libro del viaje). Se trata de su obra titulada Nufädat al-yirāa fì 'ulālat al-igtirāa $b^{2}$, una obra de la que solo nos han llegado dos partes ya editadas, y en la que reúne de forma miscelánea diversos materiales conectados con sus años en el Magreb. Las narraciones históricas de los acontecimientos en una y otra orilla aparecen interrumpidas por compilaciones de su correspondencia y poesía. En toda esta amalgama aparentemente caótica destacan dos relatos de viajes que representan la expresión más personal de su experiencia ${ }^{3}$. Y es en el segundo de estos relatos, por la singularidad de su contexto y su peculiaridad, donde centramos este estudio.

Este segundo viaje que emprendió Ibn al-Jațīb el sábado 23 de $r a b{ }^{\prime}$ II de 763 (19 de febrero de 1362$)^{4}$, y que tenía Marraquech como punto de llegada, se produjo en un momento de gran agitación, tanto en la península como en el norte de África. Pedro I de Castilla se encontraba en guerra con Enrique de Trastámara apoyado este último por Pedro IV de Aragón. Las disputas dinásticas granadinas estaban íntimamente conectadas con estos acontecimientos, pues Muhammad V contaba con el apoyo de Castilla, cuando esta no estaba inmersa en su guerra civil, y Aragón con el de Muhammad VI el Bermejo, usurpador del trono de Granada posiblemente por intervención de Pedro IV ${ }^{5}$. Y tanto Fez como Tremecén no se quedaban al margen.

El 17 de šawwāl de 762 (20 de agosto de 1361) ${ }^{6}$ Muhammad V cruzaba el estrecho hacia al-Andalus para recuperar el trono que estaba en manos del Bermejo con ayuda castellana y meriní. En relación a los acontecimientos que sucedieron después hasta su entrada en la ciudad el 20 de ŷumādà II de 763 (16 de abril de

\footnotetext{
${ }^{2}$ Para una aproximación a las características y contenido de esta obra, ver JREIS NAVARRO, Laila M. "Cartas y noticias de ambos lados del Estrecho: el universo jatibiano a través de la Nufädat alŷirāb", en Miscelánea de Estudios Árabes y Hebraicos (Sección Árabe-Islam) 62 (2013) 83-106 (http://digibug.ugr.es/bitstream/10481/23054/1/Jreis13.pdf).

${ }^{3}$ Para una ampliación sobre el contexto general de esta obra y sobre las etapas y motivaciones de ambos viajes, ver JREIS NAVARRO, Laila M. "La riḥla jatibiana a través de la Nufāạdat al-ŷirāb de Ibn al-Jațīb", en Saber y poder en al-Andalus, 217-49.

${ }^{4}$ IBN AL-JAṬ̂̄B, Nufādat al-ŷirāâ, ed. al-Sa diyya Fāgiya, Casablanca 1989, 85.

${ }^{5}$ BECERRA HORMIGO, Manuel, "La conexión catalana en el derrocamiento de Ismail II", en Miscel.lània de Textos Medievals 4 (1988) 301-17.

${ }^{6}$ IBN AL-JAṬīB, Al-Lamha al-badriyya, ed. Muhammad Mas ‘ūd Ŷubrān, Bengasi 2009, 151.
} 
1362) ${ }^{7}$, Aḥmad Mujtār al- 'Abbādī sugiere la posibilidad de que Muḥammad V sacrificara territorio musulmán en un pacto secreto con Pedro I para atacar Granada por dos frentes y lograr así debilitar la resistencia granadina, sin olvidar que su alianza con el infiel no habría sido bien vista a ojos de los musulmanes ${ }^{8}$. Ibn al-Jațīb en la Nufäda, dice que el monarca granadino quedó libre de toda sospecha', pero ya el hecho de que lo mencionara tiene su propia significación. Lo cierto es que, de ser así, la estrategia era buena. La amenaza castellana hacía más fácil a Muḥammad V avanzar por un territorio atemorizado con la aparente imagen del legítimo monarca que vuelve en defensa de los musulmanes que se hallaban en caos por las fechorías de un usurpador que estaba siendo hábilmente desacreditado. Sea como fuere, este es el panorama del que Ibn al-Jațīb trataba de huir permaneciendo en el Magreb. Su desaliento estaba justificado, pues el reducto del Islam peninsular se mantenía a duras penas.

Sin embargo, la situación en el reino meriní no era más alentadora. Al igual que en Granada, las disputas dinásticas y el despotismo de los visires debilitaban el reino y permitían la intervención de los rivales en sus asuntos internos. Durante el breve espacio de tiempo que duró el exilio del visir granadino en el Magreb se sucedieron nada más que tres sultanes. Y es precisamente tras la subida al trono del tercero de estos, Abū Zayyān, venido desde Castilla por intervención de Muḥammad V, que Ibn al-Jațîb inicia su viaje poco antes de verse obligado a volver a Granada. Todo formaba parte de la maniobra del visir magrebí 'Umar b. 'Abd Allāh al-Yābānī que se había hecho con el poder en Fez destronando y entronizando sultanes a su antojo. A causa de su despotismo y de sus maniobras políticas para mantener su posición, el reino se había dividido en tres: él en Fez con el sultán Abū Zayyān; el señor beréber del sur Abū Tāābit 'Āmir al-Hintātī en Marraquech con el emir meriní Abū l-Faḍl supeditado al primero por un pacto con al-Yābānī; y el emir 'Abd al-Halīm en Siŷilmasa, enviado por el Bermejo, junto con su hermano 'Abd al-Mu'min y su sobrino, con apoyo de los Zayyāníes de Tremecén para hacerse con el trono de Fez.

Al-Yābānī había conseguido hacer frente a 'Abd al-Halīm y sus partidarios con la ayuda de ciertas tribus árabes y bereberes cuyos apoyos resultaban cruciales en las disputas por el trono. El visir contaba con Abū Țābit 'Āmir, líder de los Hintāta, la tribu beréber mașmūda que dominaba el sur magrebí desde tiempos almohades, tras el mencionado acuerdo mediante el cual se dividieron el reino meriní haciéndose este último independiente en el sur. Su otro apoyo, aunque más incierto que el primero, era Mubārak b. Ibrāhīm, jeque de los Julț, la tribu árabe que dominaba el llano de Tāmasnā en tiempos meriníes tras sustituir a los Sufyān, aliados de los almohades. Y es en torno a la actuación de estos en este conflicto magrebí que giran

\footnotetext{
${ }^{7}$ Idem 154.

${ }^{8}$ AL-'ABBĀD̄̄, Aḥmad Mujtār, El reino de Granada en la época de Muḥammad V, Madrid 1973, 51-2.

${ }^{9}$ IBN AL-JAṬ̄̄B, Nufā
} 
todas las incógnitas que rodean el viaje de Ibn al-Jațīb desde Fez hacia Marraquech pasando por Tāmasnā, donde se desarrolla el relato.

Lo cierto es que la posición de Mubārak al-Julțī y de 'Āmir al-Hintātī en la contienda por el trono tras el asesinato del sultān meriní Abū Sālim por orden del visir 'Umar b. 'Abd Allāh el 17 de $\underline{d} \bar{u} l-q a$ 'da de 762 (18 de septiembre de 1361) ${ }^{10}$ no era clara. Mubārak se había aliado en primer lugar con los meriníes, encabezados por el jeque Yahyà b. Raḥhū, que se habían opuesto a al-Muwaswas, primer candidato de al-Yābānī al trono, reuniéndose en torno a 'Abd al-Halīm y cercando y atacando $F^{11}$. Cuando el ataque fracasa y desembarca Abū Zayyān, siguiente candidato de al-Yābānī, en Ceuta, Mubārak toma la posición a favor de este último alejándose del jeque meriní y acercándose a la posición de al-Hintātī12. Este hábil y poderoso señor beréber, que había ya eliminado al gobernador de Marrakech tras enterarse del asesinato de Abū Sālim, había acordado la división del reino a cambio de acudir en auxilio del visir con el príncipe meriní Abū l-Faḍl como pretendiente en caso de que los rebeldes consiguieran impedir la llegada de Abū Zayyān a la capital.

Entronizado Abū Zayyān en Fez los disturbios seguían en pie al sur de esta entre las tribus aliadas de unos y de otros que aprovechaban la coyuntura para ganar poder. Ibn al-Jațīb, que había viajado desde Salé a Fez para prestar obediencia al nuevo sultán, emprende su viaje en medio de las agitaciones y en dirección al foco del conflicto ${ }^{13}$. Los árabes de Tāmasnā se habían reunido para someter a los beréberes Haskūra ${ }^{14}$ que apoyaban la facción de 'Abd al-Ḥalīm. Pretendían estos, según Ibn alJațīb, hacerle frente al poder expansivo de al-Hintātī, que se hacía fuerte en el sur tras debilitarse el gobierno de Fez. Mubārak, que como ya se ha señalado había acercado posiciones hacia al-Hintātī, iba en nombre de este para hacer entrar en razón a los Haskūra. Estos, hartos igualmente, como muchos otros, del autoritarismo de los árabes de Tāmasnā, deciden tenderles una trampa que acaba en su masacre.

Con esto al-Hintātī había conseguido debilitar a unos y a otros enfrentándolos y manteniendo así su posición fuerte en Marrakech con el monte Hintāta a sus espaldas como refugio infranqueable. El poderoso señor del sur, cuyo único apoyo a alYābānī durante el conflicto había consistido en ejercer presión sobre los rebeldes estableciéndose en Casablanca con su ejército, había pasado por Fez para hacer cumplir el pacto y se encontraba en el momento de la mascare cerca del monte de los Haskūra. Había estado haciendo frente a 'Abd al-Mu'min que tras su derrota en Mequínez trataba de someter a los árabes de Tāmasnā que habían abandonado a su

${ }^{10}$ IBN JALDŪN, Tārīj Ibn Jaldūn, ed. Jalīl Šahāâda y Suhayl Zakkār, Beirut 2000, vol. VII, 415.

${ }^{11}$ Idem, 416-20.

${ }^{12}$ IBN AL-JAṬīB, Nufāọat al-ŷ̀irāb, ed. Aḥmad Mujtār al-‘Abbādī, El Cairo 1967, 323.

${ }_{13}^{13}$ IBN AL-JAṬīB, Nufāda, ed. Fāgiya, 107-10.

${ }^{14}$ Tribu de los beréberes mașmūda cuyo territorio era contiguo al de los Hintāta por el norte. Aunque se contaron entre las tribus que apoyaron la causa almohade, no fueron de las primeras en hacerlo como fue el caso de los Hintāta. Cuando los meriníes tomaron el poder, les ofrecieron igualmente resistencia en un principio hasta que al final tuvieron que someterse (IBN JALDŪN, Tārīj, vol. VI, 271). 
hermano 'Abd al-Halīm. Una vez debilitados todos, vuelve a Marraquech y proclama al emir Abū l-Faḍl, con la condición de mantener la obediencia al sultán en Fez, y se independiza en el sur magrebí. El encuentro con el hombre astuto del momento, como lo califica Ibn al-Jațīb tras describir sus triquiñuelas ${ }^{15}$, era de nuevo uno de los objetivos de su segundo viaje al sur.

En este contexto Ibn al-Jațīb realiza su viaje por los llanos en pleno invierno. Un viaje repleto de incógnitas. La riḥla (relato de viaje), traducida en este estudio, en la que describe el autor las etapas de su viaje, está inconclusa. Las claves para comprender su inconclusión vienen al comienzo del apartado de la Nufäda en el que está inserta y en dos versiones muy distintas entre sí. Según la versión oficial, que es la que ofrece al sultán Abū Zayyān en la carta ${ }^{16}$ que le envía a su vuelta del viaje y en la que le adjunta y dedica la mencionada riḥla: a mitad del llano de Tāmasnā Ibn al-Jațīb cae enfermo y se ve obligado a volver con la intención de reanudar la marcha en mejores condiciones. Pero la verdadera razón por la que tuvo que volver a mitad de camino fue otra. El autor precede esta carta con la auténtica explicación de los hechos ${ }^{17}$ : el territorio que atravesaba se hallaba agitado y la gente se encontraba en un estado deplorable, sometida a los abusos de los jeques árabes que aprovechaban el vacío de poder causado por la fitna (guerra civil). Confiesa Ibn alJațīb que se negó a atravesar sus inseguras fronteras pues parecía que habían perdido el temor al soberano. Decide por ello ponerle fin al viaje y lo hace mientras está a la espera de que Mubārak al-Julți le conceda audiencia, una audiencia que se retrasaba por lo que resuelve huir de noche. Y aunque al enterarse Mubārak manda en busca del visir alegando la gran ofensa que a su honor eso suponía, el granadino se niega a retroceder y continúa su marcha hasta Salé. Y es justo después de este desencuentro que Mubārak se dirige con las tribus árabes a su encuentro con los Haskūra ${ }^{18}$. Meses después, entre $\check{s} a$ ' $b \bar{a} n$ y ramaḍān del mismo año, será cuando alYābānī salga al encuentro de 'Abd al-Halīm que permanecía en Siŷilmāsa con la intención de volver a atacar Fez, acabando el encuentro en tregua ${ }^{19}$.

¿Cuál era el objeto del encuentro de Ibn al-Jațīb con Mubārak en semejantes circunstancias? No olvidemos que tanto Marraquech como el encuentro con al-Hintātī eran destino y móvil del viaje. De hecho, tras la amputada riḥla, Ibn al-Jațīb incluye una serie de materiales dispersos que tenía intención de incluir en el relato de haber llegado el viaje a su fin, y entre ellos figura un largo poema dedicado a este último.

${ }^{15}$ IBN AL-JAṬīB, Nufāda, ed. Fāgiya, 109.

${ }^{16}$ Esta carta la estudia Aḥmad 'Azzāwī en su obra Riŷāl al-idāra wa-l-a yyān fí l-'aṣr al-marīn̄̄ min jilāl rasā’ il šajșiyya li-Ibn al-Jațīb, Rabat 2010, 35-6.

${ }^{17}$ IBN AL-JAṬīB, Nufāḍa, ed. Fāgiya, 85-6.

${ }^{18}$ IBN AL-JAṬīB, Nufāda, ed. Fāgiya, 107.

${ }^{19}$ IBN JALDŪंN, Tārīj, vol. VII, 423. 
Este movimiento de Ibn al-Jațīb en medio del conflicto anteriormente expuesto recuerda al retorno de Ibn Bațtūța al Magreb y su posterior viaje al reino de Malí emprendido en 1352. Ibn Bațtuṭa vuelve a su tierra tras su largo viaje en un momento en el que el fracaso del sultán magrebí Abū 1-Ḥasan en Ifriqiyya había provocado que su hijo Abū 'Inān se hiciese con el trono meriní en Fez. De hecho, al encontrarse en su viaje de vuelta con uno y luego con otro, se ha supuesto su papel de contacto entre ambos y de informador de Abū 'Inān sobre la situación de los territorios del norte de África durante este conflicto. Todas estas agitaciones que se produjeron en el Magreb tras la caída del Imperio Almohade y especialmente durante el siglo XIV (VIII de la hégira) tenían su reflejo y causa en el debilitamiento del comercio saharaui con el reino de Malí, que en las primeras décadas del siglo comenzaba ya a mirar al Egipto Mameluco en busca de unas vías seguras de contacto comercial. Tras la caída en desgracia del sultán Abū l-Ḥasan, que todavía mantenía esas relaciones con cierta estabilidad, estas se ven interrumpidas durante el reinado de su hijo y usurpador al trono. Abū 'Inān había aprovechado el fracaso del intento de su padre de apoderarse del norte de África y de sus enclaves comerciales, para debilitar su posición y hacerse con el control del Magreb al-Aqșà, que entra a partir de su muerte en su periodo de decadencia debido, entre otras causas, a la crisis económica que debilitaba al gobierno. La situación anteriormente narrada en la que se produjo el viaje de Ibn al-Jațīb no era más que un reflejo entre tantos de ese debilitamiento.

Se ha querido ver en el viaje de Ibn Bațtuța al reino de Malí una misión oficial encomendada por el sultán Abū 'Inān al viajero para recuperar de algún modo esos contactos comerciales con el sur del Sáhara y mantener así el lucrativo intercambio de sal por oro subsahariano que se mantenía desde hacía siglos. El viajero en su relato no expone este posible móvil de forma explícita por lo que se baraja también que se le hubiese encomendado la tarea de recoger información, poniendo en juego sus habilidades como experimentado viajero, sobre la situación del comercio en dicho reino. De hecho, Ibn Batțūta pone de manifiesto la actitud distante del sultán de Malí hacia su persona, probablemente síntoma del cambio y de que empezaban a soplar otros vientos para el Magreb meriní. ${ }^{20}$

Ibn al-Jațīb durante su exilio y sus viajes, especialmente este, no está muy alejado del contexto descrito para el tangerino, y no se descarta que igualmente se haya movilizado en situación tan agitada hacia el foco del conflicto de su momento por encargo de al-Yābānīîn, aprovechando su aparente imparcialidad en las disputas,

\footnotetext{
${ }^{20}$ Para ampliar información sobre estas hipótesis: AL-FASĪ, Aḥmad, "Mawqi“ riḥlat Ibn Baț̣ūṭa fī 1-mašārī‘ al-siyāsiyya wa-l-iqtișādiyya li-l-sulțān al-marīn̄i Ab̄̄ 'Inān”, en Ibn Battuta. Rencontres internationales Ibn Battuta de la comunication intelectuelle. Tanger: 27-28-29 Octobre 1993, (1996), 143-160. Y en las mismas actas: Ḥ̂ĀFIẒ̄ 'ALAWĪ, Ḥasan, “"Alāqat al-Magrib al-aqșà bi-Mālī min jilāl riḥlat Ibn Baț̣̂uṭa", 183-204.

${ }^{21}$ Al-Šāhidī propone la hipótesis de que este viaje haya podido ser un encargo del monarca meriní, ya para orar por él en los lugares santos ya para cultivar sus relaciones con los jeques árabes de la zona
} 
su excepcional habilidad de gobierno y su amplia experiencia política. Es lógico pensar que el gobierno de Fez en semejante coyuntura necesitaba para ganar poder estabilizar la situación en la zona cuanto antes y así poder recaudar de nuevo los tributos necesarios con el fin de recuperar su posición de autoridad. La actitud de alHintātî de aumentar la agitación con el fin de mantener su propia independencia no le hacía ningún bien a la soberanía de la capital pues las lealtades eran inciertas y el pueblo sufría las consecuencias de la guerra civil.

Desde luego el relato del viaje que viene traducido a continuación no refleja la realidad de la situación que vio el autor en su trayecto más que tangencialmente. Parece mucho más realista un pequeño párrafo que le precede y en el que Ibn alJațị ofrece una visión más cruda del mismo territorio. Nos habla de miseria, miedo, hambre y despotismo ${ }^{22}$. El desencanto del exiliado sabio andalusí no pudo ser mayor en el panorama del Occidente musulmán del momento.

La rịhla objeto de este estudio y traducción la escribe Ibn al-Jațīb en prosa rimada en un lenguaje encriptado y condensado, muy alejado del acostumbrado en este género. El mismo texto con ciertas variantes figura en su obra Rayhāanat al-Kuttā $b^{23}$ incluido entre un grupo de epístolas literarias, sin carta ni borradores finales. Esta selección de epístolas comienza con una que dedica a Abū 'Inān, fechada el 9 de muharram de 756 (14 de enero de 1355) y escrita en Ceuta antes de hacerse a la mar, probablemente tras su famosa embajada. En ella hace alarde de sus artes retóricas incluyendo la letra $\operatorname{Sin}$ en cada una de las palabras del texto. Después se incluye su Jatrat al-țayf wa-rihlat al-šita ' wa-l-șayf, el relato del viaje que realiza en la primavera de 1347 acompañando al sultán nazarí Yūsuf I en su inspección de la frontera oriental del reino. Posteriormente viene el texto de nuestra rihla sucedida por su epístola sobre los gobernadores magrebíes en tiempos de Abū Sālim Qaț alfalāt bi-ajbār al-wulāt que también viene en la Nufäda $a^{24}$. Y finalmente su maqāma (epístola literaria en prosa rimada) sobre la geografía andalusí y magrebí Mi yār alijtiyāssr fí dikr al-ma āhid wa-l-diyār. Estas dos últimas las escribió durante su exilio al igual que el texto traducido. Una selección nada gratuita, pues todas están relacionadas con viajes que realizó por al-Andalus y el Magreb ${ }^{25}$.

Se ha seguido en la traducción la versión del texto que figura en la tercera parte de la Nufäda editada por al-Sa'diyya Fāgiya y el estudio que de este ha realizado

en vistas a lograr mayor seguridad y estabilidad (AL-ŠĀHIDĪ, al-Ḥasan, Adab al-rihla bi-l-Magreb fil- 'așr al-marīnī, Rabat 2002, vol. II, 461).

${ }_{22}^{2}$ IBN AL-JAṬĪB, Nufāọa, ed. Fāgiya, 85-6. Traducido al castellano en JREIS, "La riḥla jatibiana", 237-8.

${ }^{23}$ IBN AL-JAṬ̄̄B, Rayḥānat al-kuttāb, ed. Muḥammad ‘Abd Allāh 'Inān, El Cairo 1981, vol. II, 264-70.

${ }^{24}$ IBN AL-JAṬīB, Nufā da, ed. al-'Abbādī, 151-62.

${ }^{25}$ Idem, 122. 
$\bar{A}$ ḥmad 'Azzāwīi'. Se ha tratado de mantener el estilo jatibiano del texto original para poder así saborear en lo posible sus sutilezas y no perder las magníficas imágenes retóricas que perfilan su visión y su exquisito lenguaje. Por ello, se ha acompañado donde se ha creído necesario de breves aclaraciones que tratan de esclarecer estas imágenes y el uso intencionado de determinados vocablos. Se pretende con esto dejar la puerta abierta a nuevas interpretaciones de las múltiples que entraña la riqueza de esta recamada epístola. En algunos casos se ha creído conveniente salirse de la edición de Fāgiya por no aceptar sus correcciones al manuscrito o se ha recurrido a la versión de la riḥla en la Rayhạna por considerar que guarda más sentido con el contexto, y así se ha señalado en los lugares correspondientes.

\section{El viaje por Tāmasnāa ${ }^{27}$}

[p. 87] Cuando se apresuró el siervo de su dignidad en compañía de su obediente delegación y el almocadén de su majestad y su tropa, prestando en la premura el límite de su capacidad, volando con el ala del amor en cuanto le fue posible, vio que se había independizado con el trono quien de él se había apoderado ${ }^{28}$ y que se habían estabilizado las bases ${ }^{29}$ del poder. Conque cumplió con el deber ${ }^{30}$. Recitó y lo hizo bien. Expuso los escuadrones de la alabanza, abarcó el propósito ${ }^{31}$ y llenó con ellos la tierra, y partió de vuelta ${ }^{32}$ arrastrando el rozagante vestido de la gloria. Y requirió el permiso [de su majestad] para visitar el territorio [p. 88] marraquechí y obsequiar [con ello] a quien se ausentó durante su compleción ${ }^{33}$, felicitar a los fieles con el término del asunto y el éxito de su resultado, y procurar la baraka del sepul$\mathrm{cro}^{34}$ que satisface al anhelante en sus ruegos. Y le pareció registrar el curso de su

${ }^{26}$ 'AZZĀWĪ, Aḥmad, Raḥalāt li-Ibn al-Jațīb bi-l-Andalus wa-l-Magrib. Nuṣūṣ talāt rahalāt ma'a qirā'a tārījiyya, Rabat 2012, 65-87.

${ }^{27}$ Esta epístola carece de título original. La paginación que figura a lo largo de la traducción corresponde a la edición de Fāgiya y el texto original figura en el anexo.

${ }^{28}$ Se refiere a la reciente subida al trono del sultán Abū Zayyān a quien se dirige Ibn al-Jațīb con esta rihla.

29 “Manāṣib" en la Rayḥāna.

${ }^{30}$ El de visitar al sultán recién entronizado en Fez para prestarle obediencia y alabarle.

31 "Al-garaḍ" en el manuscrito y en la Rayhāna. No se acepta la corrección de Fāgiya.

${ }^{32}$ Puede que a Salé y de ahí emprendiese el viaje, pues no lo especifica en la riḥla. Antes de ésta Ibn al-Jațīb menciona que emprenden la marcha hacia Marrakech en la señalada fecha y que hacen su primera parada en 'Ayn Gabūla que la editora sitúa cerca de Salé (IBN AL-JAṬ̄īB, Nufāộa, ed. Fāgiya, 85). 'Azzāwī deduce por ello que pasó por Salé antes de emprender el viaje ('AZZĀWĪ, Rahalāt, 66).

${ }^{33}$ Se refiere a su gran hazaña de hacerse con el trono de Fez.

${ }^{34} \mathrm{Tal}$ vez se refiera al sepulcro del santón ceutí del s. XII Abū 1-'Abbās al-Sabtī en Marraquech. Era tan conocido que hasta los monarcas recurrían a él con sus ruegos e incluso se sellaban en torno a su tumba pactos políticos (IBN AL-JAṬĪB, Nufāda , ed. al-'Abbādī, 305). De hecho, Ibn al-Jațīb le dirige unos versos puestos en boca de Muhammad V cuando este todavía se encontraba destronado en Fez en los que se invoca su amparo en la recuperación de Granada (IBN AL-JAṬĪB, Nufāḍa, ed. al-'Abbādī, 381). 
viaje (rihhla) dedicado a atender su asunto, y romper el cáliz de su gloria en flor ${ }^{35}$, apoyándose en Dios en su fuero interno y a voz alzada. Así que dijo:

Salimos de la madre de las villas ${ }^{36}$, el lugar de reunión de los hombres y la Caaba de la marcha y el viaje nocturno ${ }^{37}$. La ciudad de Fez. Sede del poder legítimo y de la gloria alzada y derramada, donde los blancos palacios, el largo y ancho dominio, las custodiadas puertas, los cultivados huertos, las precipitadas aguas, las asalariadas tropas, las majestuosas construcciones, las imponderables estancias, y la religión y vida terrena $^{38}$. Sin condición ni excepción, que Dios la proteja y guarde, y multiplique - y lo ha hecho - su muchedumbre, nos volvemos hacia los [conocidos] lugares de encuentro de los señores, la adhesión del afecto y las atalayas de los generosos.

Ellos nos han alojado en las sombras de sus casas, sombras de casas que han abrigado y protegido.

Rehusaron cansarse de nosotros, y si nuestra madre

hubiera recibido lo que ellos de nosotros, se habría casado. ${ }^{39}$

Nos acompañó para despedirnos - de entre aquellos cuyo amparo fue generoso y reconocida en el dominio de la lealtad su experiencia - un grupo de jefes, soles y plenilunios. Recordé en [el momento de] su despedida, que suscita el llanto y los atorados lagrimales, el dicho de nuestro maestro Abū l-Barakāt ${ }^{40}$ :

Oh aquel quien si quiero despedirle,

me despido de mi corazón antes de hacerlo.

Y paso mi noche en vela desconcertado,

engañando el alma con algún engaño.

Oh aflicción del alma por su compañero, ${ }^{41}$

a causa de él se ha presentado esta migraña.

${ }^{35}$ Este tipo de expresiones figurativas son muy propias del lenguaje jatibiano, especialmente cuando emplea la prosa rimada como es el caso. Una interpretación posible que ofrecemos a esta expresión es que el visir pretende abrir con su relato la flor, entendida como fruto, de su viaje que permanecía hasta el momento en capullo. Vuelve a utilizar la figura más adelante en otro contexto.

${ }^{36}$ Se utiliza la expresión "Umm al-qurà" para referirse a La Meca.

${ }^{37}$ Aquí Ibn al-Jațî̉b hace un juego de palabras con "umm al-qurà", "la madre de las villas" e "ibn al-surà", el "viajero nocturno", que literalmente significa "el hijo del viaje nocturno". Curiosamente utiliza también la palabra "wară", "humanidad" o "creación", traducida como "hombres", siendo "abū l-warà", "el tiempo", literalmente "el padre de las criaturas".

${ }^{38}$ Según 'Azzāwī, Ibn al-Jațīb hace referencia a los hombres de religión y a los hombres de negocios ('AZZĀWİ, Rahalāt, 76).

${ }^{39}$ Fāgiya ha identificado estos versos como similares a los del poeta preislámico Țufayl al-Ganawī (Dīwān Țufayl al-Ganawī. Šarh al-Aṣma; ed. Ḥassān Falāḥ Ūglī, Beirut 1997, 130). Ibn al-Jațīb incluye estos mismos versos en su maqāma titulada Mi ‘yār al-ijtiyār (IBN AL-JAṬĪB, Rayhāāna, vol. II, 281).

${ }^{40}$ Según Ibn al-Jațīb, su maestro Abū l-Barakāt al-Balafĩqī le dedica estos versos en una ocasión en la que salió el autor a despedirle (al-Katība al-kāmina, ed. Iḥsān 'Abbās, Beirut 1983, 134). Para más información sobre este personaje ver: AL-HARRĀMA, 'Abd al-Ḥamīd 'Abd Allāh, Ši 'r Abī l-Barakāt Ibn al-Hāŷy al-Balafìqū, Dubai 1996; y DE LA PUENTE, "Al-Balafīqī, Abū l-Barakāt”, en Biblioteca de al-Andalus, J. Lirola Delgado y J. M. Puerta Vílchez (eds.), Almería 2012, vol. I, 160-4.

${ }^{41}$ Fāgiya ha corregido este hemistiquio basándose en la versión mencionada de los versos en la Katība. 
Pernoctamos en la aldea ${ }^{42}$ de al-Buwayyir ${ }^{43}$, de los alfoces [de Fez]. Una aldea en la que el camino ha aventado ${ }^{44}$ la humedad de su gente ${ }^{45}$, y ha aniquilado [en ella] Dios la virilidad del joven y del adulto. Al día siguiente recorrimos hacia la ciudad de Mequínez la etapa poblada y el camino que no pasa hambre ni sed, donde la extendida llanura, la existente agua, los curvados puentes, las magníficas aldeas y los vestigios meriníes. Y de ella hay mucha distancia.

Cuando el sol empezó a trepar las tapias ${ }^{46} \mathrm{y}$ a conducir a su gente a la parte trasera de los aposentos, y comenzó su oro a dorar la plata de la mañana y su navaja decorada a rasurar la mejilla [p. 89] de la tierra después de que se dejó crecer la barba, comenzamos a llenarnos de un sentimiento de entereza por la separación mientras esta ponía en evidencia, y a compendiar la sentencia de la tristeza mientras las lágrimas glosaban, así que despedimos al grupo acompañante y tomamos el camino poco claro. Había cubierto una niebla que tenía sobre la tierra un afinco que ocultó las direcciones y mezcló los caminos principales, y nos perdimos, pero Dios nos guió, y marchamos vestidos con las nubes y envueltos ${ }^{47}$. La vegetación había hecho salir sus brotes y lo desgastado de las ruinas se había engrosado ${ }^{48}$. Después el sol limpió de óxido ${ }^{49}$ el espejo del horizonte y dio a cada alma su buen camino ${ }^{50}$, y agradecieron los viajeros nocturnos su refugio matutino ${ }^{51}$.

Nos precipitamos en al-Raml ${ }^{52}$-cuyo pasto hizo crecer Dios y congregó a sus corderos que acudieron a la llamada - entre tiendas, pastores no avaros, jaimas, echaderos de

\footnotetext{
${ }^{42}$ La palabra que utiliza Ibn al-Jațî̉ es "dišāar" pl. "dušur", utilizada en el Magreb en el sentido de "pueblo" o "aldea" (DOZY, Supplément, Leiden 1881, vol. I, 443).

43 'Azzāwī sugiere que pueda ser diminutivo de "bi' r", "pozo", y la sitúa al oeste de Fez en el camino hacia Mequínez ('AZZĀWĪ, Rahalāt, 71). Por ello se acepta la propuesta de vocalización de 'Inān en la Rayhāna en lugar de la de Fāgiya en la Nufăda ("Buwayr").

${ }^{44}$ No se admite la corrección de Fāgiya del manuscrito en este punto pues sustituye "nasafa", "aventar", por "našafa", "secar". En el texto de la Rayhāna, vol. II, 266, viene como "naša 'a", "arrancar con fuerza".

${ }^{45}$ El paso continuado de los viajeros por el camino que atraviesa la aldea ha terminado con la generosidad de sus habitantes. El uso de "humedad" por "generosidad" es un tópico común.

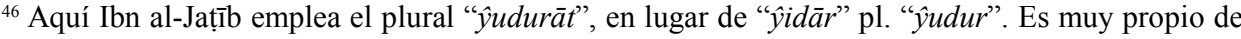
su estilo el empleo de plurales poco comunes.

${ }^{47} \mathrm{El}$ autor aquí juega con la polisemia de los dos verbos: "alhafa" y "raddà" creando dos sentidos en la frase: las nubes les envolvían cual vestido y abrigo en un sentido, y en otro, les importunaban y les hacían caer". Esto es muy característico del lenguaje jatibiano y no siempre fácil de percibir. 'Inān lee aquí "wirdān" como una palabra en sí misma (Rayhāna, vol. II, 266).

${ }^{48}$ Se refiere a que los cantos de las ruinas se habían hinchado a causa del agua.

${ }^{49}$ En el texto viene "șadāhä" en lugar de "sada' ahä".

${ }^{50}$ El Corán $(32,13)$.

${ }^{51}$ Según Fāgiya, Ibn al-Jațīb toma esta expresión del proverbio árabe que dice: "al amanecer los viajeros agradecen el viaje nocturno" ( 'ind al-șabāh yaḥmad al-qawm al-sarà). Ver no 213 en OULD MOHAMED BABA, Ahmed-Salem, "Los proverbios árabes clásicos más usados", en Anaquel de Estudios Árabes 23 (2012) 131-144.

${ }^{52}$ Según 'Azzāwī es una zona de bosque al norte de Tāmasnā y este de Casablanca ('AZZĀWī, Rahalāt, 77).
} 
ganado $^{53} \mathrm{y}$ boñigas, rebaños que llenan la tierra, vacas con las que se estrecha la superfi$\operatorname{cie}^{54}, \mathrm{y}$ ancianas que perdieron la esperanza de la menstruación, obsequiantes de los odres de leche desnatada. Se ha agitado en el vasto campo el campamento del comisionado ${ }^{55}$, teniendo éxito sus esfuerzos, pues las manadas se cuentan, las tierras se extienden, y la autoridad de los que se ocupan de ellas no se refuta.

Antes de que se instalase el sol en lo alto del meridiano y se dejase caer de las partes altas de las patas ${ }^{56}$ [los mechones de la oscuridad, hicimos alto en 'Ayn alŠa ${ }^{6} \mathrm{ră}^{\prime}{ }^{57}$. Nos apartamos de $]^{58}$ su fortaleza hacia el campo raso, una fortaleza descantillada y derruida, lo existente de urbanidad en ella está perdido, excepto que es abundante en leña, una parada a la que dirigirse, una mina de hierro y la entrada del largo y ancho país. Plantamos las tiendas en su exterior por temor a sus pulgas, y no temimos sus fieras que rugen a nuestro alrededor ni sus leones. Se dio la inusitada protección, resultó seguro - y el favor es de Dios - el arrebato, y experimentamos la beneficencia de su proximidad y no estuvimos privados de la benevolencia ni el peso de una mota ${ }^{59}$.

Nos pusimos en marcha por la mañana y el ojo del sol con la blancura de la niebla precisaba de alcoholarse. Tomamos el camino de la zanja de Hārūn, la campiña de Jirāz ${ }^{60}$, el campo de duelo ${ }^{61} \mathrm{y}$ la presunción de la precaución, hacia la aldea de Makūl ${ }^{62}$, que está a la perdición encomendada ${ }^{63}$, y con el pie de la devastación por los beduinos pateada. Y cuando vimos que su espacio estaba deshabitado, y que se había distinguido con la ropa de junco ${ }^{64}$, la atravesamos hacia Māgūs, la aldea de al-Zāwiya, el centro de los caminos paralelos ${ }^{65}$, el lugar de alto de las caravanas nocturnas, y la urbe de Tāmasnā, donde está la audiencia de su cadí, la riña de su indignado y de su complacido, y el baño de quien hace sus abluciones. Una aldea

${ }^{53}$ Concretamente aquellos que se sitúan cerca del abrevadero.

${ }^{54}$ Dice literalmente: la largura y la anchura.

${ }^{55}$ Según 'Azzāwī, se trata del recaudador de impuestos ('AZZĀWĪ, Rahalāt, 78).

${ }^{56}$ Probablemente se refiera a las patas de las monturas.

${ }^{57}$ Mencionado el topónimo en IBN ABĪ ZAR', al-Dֵajīra al-saniyya, ed. Muhamammad b. Abī Šanab, Argel 1920, 137.

${ }^{58}$ Esta parte entre corchetes falta en el manuscrito de la Nufäda y la ha completado la editora de la versión de la Rayhạna.

${ }^{59}$ Es una expresión muy utilizada para referirse a una cantidad inapreciable.

${ }^{60}$ Este topónimo lo sitúa al-Idrīsi cerca de la aldea de Makūl (ver nota correspondiente).

${ }^{61}$ Se refiere al campo de batalla donde tienen lugar duelos o combates singulares.

${ }^{62}$ Fāgiya y 'Azzāwī identifican el topónimo en tres obras: IBN ABĪ ZAR', al-Anīs al-mutrib birawọ al-qirțās, Rabat 1972, 329, en la que se indica que el sultán meriní Abū Yūsuf Ya'qūb pasó por esta aldea de Tāmasnā en su camino de Marraquech a Tánger en dirección a al-Andalus en 1279, y en

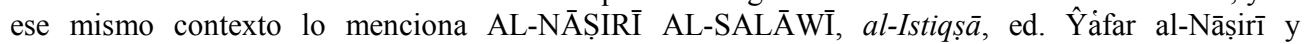
Muhammad al-Nāṣirī. Casablanca 1955, vol. III, 50. También viene en AL-IDRĪSĪ, Nuzhat al-muštāa El Cairo, 238.

${ }^{63}$ Error en la edición. La palabra tanto en el manuscrito como en la Rayhāna es "mawkūl".

${ }^{64}$ Es decir, el lugar estaba lleno de juncos y era inhabitable.

${ }^{65}$ En la Rayḥāna figura otra expresión que vendría a significar "el centro de las partes equivalentes". 
grande, [que] come de granero y bebe de pozo ${ }^{66}$. Ha perdido el esplendor y está privada de las comodidades de la civilización, aunque asegura el almacenamiento y garantiza la custodia del grano, mientras no se eche a perder ${ }^{67}$. Se dispuso en ella una mezquita. Ha afeado la incompleción de su alminar por la insuficiencia de su dírham y de su dinar ${ }^{68}$, por lo que su aspecto es horrendo y su defensa no es inexpugnable. Pernoctamos bajo la protección de su testigo adul, que fue sordo a la crítica y se elevó por encima de la naturaleza del troque hacia la de los generosos.

Y le recité al día siguiente:

[p. 90] Qué recibimos en Māgūs de alboroto

por la noche, y de tumulto de los vigilantes y de los guardias.

Y de mala agua de la que no se nos hace fácil

beber un trago más que con dificultad.

$\mathrm{Y}$ de lenguas a nuestro alrededor barbáricas, como si estuviésemos en el país de los negros y de los nabateos.

Yermo, no hay árboles a cuya sombra acogerse,

ni quien solace y alivie el alma del desánimo.

Se ha sentado el constructor de su alminar en su edificación,

por lo que no lo señala el ojo de un gozoso.

Como si fuese un balano que han traído para circuncidarlo

a un circuncisor que cortó de este la mitad por error.

Pero el más ilustre de sus notarios,

Yahyyà, es el más piadoso joven que exige el favor.

Ha revivido en ella Yahyyà el solaz tras su soledad,

y sustituido una multitud de aquel tipo.

Partimos al día siguiente tras agradecer su hospitalidad, y alejó la caravana su paso hacia el poblado de [los] Sufyān. Atravesamos dormidos su campamento, dejamos la noticia a los testigos oculares y merodeamos entre el ganado y los campos de juego de los pastores, entre jaimas que se redondean como tajadas de giba, encerrando a niños y esposas, y aldeas cuyas chozas han montado las colinas y cuyos corderos y camellas [jóvenes] han llenado las hondonadas. Otorga su gente la leche agria después de sacar su queso y su manteca, y se impone sobre el deseoso de esta su abstinencia. Encontramos que se instaló la peste en sus casas, llevando a muchos de ellos a la tumba, y retirándose después. Y a vacas y a camellos [que han echado los primeros dientes] ha aislado y apartado. Conque no ves más que al muerto que sale, o al caballo castaño ${ }^{69}$ que para el cortejo fúnebre se ensilla, y griterío que se eleva, y gemidos donde no sirven, así que detestamos sobrevenir y nos habituamos

\footnotetext{
${ }^{66}$ Según Fāgiya, esta es otra expresión inspirada en un proverbio árabe que dice: "come trozos de pan y bebe de riachuelo" (ya'kul min ŷurf wa-yašrab min gadīr).

${ }^{67}$ Literalmente: "mientras no cause daño la izquierda de la corrupción ni la derecha". La expresión “"ạta yamīn-an wa- 'āta šimāl-an" ("creará corrupción a derecha e izquierda") viene en una tradición del Profeta sobre el Daŷŷāl (MUSLIM, Șah̄ịh Muslim, Argentina 2004, número 7015).

${ }^{68}$ Un ejemplo de la prosa rimada jatibiana volcada al castellano gracias a los préstamos léxicos.

${ }^{69}$ Caballo con pelo marrón y rojizo que debía acompañar al cortejo en estas ocasiones.
} 
al silencio [melancólico]. Nos desviamos de la zona habitada y pedimos a Dios estar a salvo del perjuicio de aquel contacto. Galopamos procurando alcanzar alBurūŷy ${ }^{70}$, donde está el campamento del jeque de esta tribu, anhelando pernoctar en el albergue no insalubre. Y dije:

¿Es que tendrá término esta marcha?

Por su causa, mis miembros se debilitaron.

Dijeron: nos dirigimos a la gran casa ${ }^{71}$; dije: renunciad

a vuestra distracción, he sobrepasado la estrella Soha ${ }^{72}$.

Declinó el sol, descendió y luego se fundió ${ }^{73}$. Y se desplomó en el seno del poniente y se derramó. Después de algo de esfuerzo llegamos, con la fatiga acabamos y el don del descanso disfrutamos Hicimos alto ante unas jaimas que se redondeaban en un cerro, cuyas cuerdas se habían enmarañado y sus formas montañosas apelotonado. Unas villas cuyas casas son pelo ${ }^{74}$, su combustible boñigas, su muralla azufaifo, y de cuya hortaliza no está exento ningún puchero. Han lindado con unas lagunas [de agua] plenas, con moradas de naciones llenas, con praderas de marcadas riberas y con vaguadas de rotos $\operatorname{sacos}^{75}$. Se apresuró el jeque y dio la bienvenida. Estuvo a gusto y actuó con familiaridad. Un hombre que ha madurado y a las canas abarcado. Indica de él el trato nobleza bajo hosquedad, y revela en él entendimiento el cáliz del descuido ${ }^{76}$. No escatimó en comida limpia ni celebración hospitalaria, una cabalgata para despedirnos en una comitiva ruidosa [p. 91] y una bondad que no se reserva ni se oculta. Preguntó por el destino y el lugar de alto de la montura, dijimos: la morada preferida del campamento de Abū Kațīi ${ }^{77}$, pues es uno de los móviles del viaje y la más válida doctrina de aquella secta ${ }^{78}$. Así que encargó a sus ojos [vigilar] nuestra mirada y separó la jornada entre nosotros y él ${ }^{79}$.

${ }^{70}$ Probablemente corresponde a la actual aldea con el mismo nombre perteneciente a la provincia de Settat.

${ }^{71}$ Utiliza la palabra "burŷy" pl. "burūŷy" que puede significar entre otras cosas: "casa en el campo" o "gran casa".

${ }^{72}$ Estrella de segundo orden de la Osa menor. Se examinaba la vista con ella por su lejanía.

${ }^{73}$ Se ha recurrido a la versión de la Rayhāna en este verbo por una repetición en la Nufäda del verbo "inhāla" en esta línea.

${ }^{74}$ Es decir, jaimas. De "bayt al-ša 'r", "la casa de pelo", por el pelo de cabra del que está hecha su tela.

${ }^{75}$ Una posible lectura de esta figura es que compara las vaguadas con unos sacos llenos de agua que al romperse hacen que esta corra en todas direcciones.

${ }^{76}$ Esta imagen ya ha aparecido antes. Quiere decir que la apariencia de descuido que tenía el hombre es como un cáliz que al abrirse revela la flor que simboliza el entendimiento que tenía en el fondo.

${ }^{77}$ Según 'Azzāwī, se trata del jeque de los Julț, Mubārak b. Ibrāhīm b. 'Alī b. Muhalhil b. 'Ațiyya ('AZZĀWĪ, Rahalāt, 82)

${ }^{78}$ Compara Ibn al-Jațīb su inclinación y la de los meriníes por los Julț, de entre todas las demás tribus árabes de Tāmasnā, con la elección de la escuela jurídica más legítima.

${ }^{79}$ Es decir, el jeque se quedó mirándoles mientras partían y después dio la vuelta para retornar. 
Paramos en el refugio de Mahdī b. Mūsà, hacia el que ha extendido la miseria ${ }^{80}$ las yemas de sus dedos, conque nos apartamos de sus cercanías y nos alejamos de la hondonada de sus casas. Y no encontró su señor entre nosotros interés por la generosidad que proporcionó ni aceptación de la comida con la que se apresuró. Le evitamos, una evasión que no le avergonzó, y pernoctamos en una guarda cuya protección se desbordó hasta que se encendió en el carbón de la noche su llama ${ }^{81}$. Cabalgamos bajo un toldo de espesa niebla y llovizna que a la niebla prefería ${ }^{82}$. No cesó el sol de sorberlo [ni] los vientos de explorarlo hasta que se disipó y se distinguió lo habitado de lo desértico.

Averiguamos durante nuestro trayecto que el camino nos reunía con nuestro anfitrión, destino de nuestro propósito, encontrándose con su grupo el nuestro, por una asamblea que entre los árabes se había acordado y un consejo presenciado por muchos. Así que dijimos: la anticipación de la reunión, la suerte de vistas tras oídas ${ }^{83} \mathrm{y}$ mayor provisión de Abū Katīir y escucha. A 12 millas se atisbaron los caballos con cuyas crines fluyen las vaguadas ${ }^{84} \mathrm{y}$ toman el aire ${ }^{85}$ con sus patas. Y disentimos sobre los caminos secundarios por parecerse, así que hicimos alto sobre las aguas de algunos de aquellos parajes.

Y le escribí con lo siguiente:

Mubārak, no he hecho preceder a Sufyān por deseo,

ni por temor a la negligencia, ni por una mala conducta.

Y no considero una mirada de mí hacia ti

más que un gran favor de Dios hacia mí.

Y si con quienes me encontré antecediéndote son estrellas,

tú eres sin duda un sol brillante.

[Pues] cuántos rezos se han hecho preceder de plegarias voluntarias ${ }^{86}$,

[y se toma antes del tarìd una harira $\left.{ }^{87}.\right]^{88}$

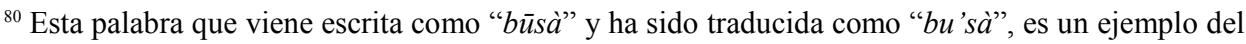
dialecto andalusí que de vez en cuando aparece en el lenguaje jatibiano (CORRIENTE, A Dictionary of Andalusi Arabic, Leiden 1997, 36). Ibn al-Jațīb la utiliza en dos versos que dedica a un emir zayyāní (IBN AL-JAṬĪB, al-Ihāṭta fì ajbār Garnāṭa, ed. Muḥammad 'Abd Allāh 'Inān, El Cairo 1874, vol. II, 292). En el primero, contrapone su sentido -y asimismo figura en Lisān al- 'arab- al de " $n u$ 'mà", "fortuna". Aunque en este contexto puede referirse con ella a la peste. En todos los casos la utiliza como recurso para favorecer la rima con el nombre propio Musà.

${ }^{81}$ Aquí Ibn al-Jațīb compara el amanecer con un trozo de carbón, oscuro como la noche, en el que se enciende cual llama la luz de la mañana. Y "ṣubāḥ" es "la llama de la lámpara" y también "luz" y "claridad". De la misma raíz que șabāh, "mañana".

${ }^{82}$ Quiere decir que a la espesa niebla se unía estrechamente una llovizna.

${ }^{83}$ Se refiere a que tienen la suerte de poder ver con sus ojos aquello de lo que se habían informado de oídas previamente.

${ }^{84}$ Compara el autor los caballos por su numerosidad con los torrentes que corren por sus lechos, y sus crines con las olas, por lo que fluyen sus crines cual torrente.

${ }^{85}$ El manuscrito no está claro y la editora propone una corrección que se puede entender como imagen de la velocidad de los caballos. En la Rayhana viene como "iŷrā", "ejecución".

${ }^{86}$ A la plegaria obligatoria se le llama "farī da" en el sentido de preceptiva. Y toda aquella que se hace sin serlo se le llama "näfila" o "nafl" en el sentido de supererogatoria. 
Después hicimos parada en al-Zāwiya ${ }^{89}$, donde está la tumba del imán y el encargado de la protección, la guarda y el cuidado. Una aldea que encontramos - y a Dios gracias - sellada sobre la salud ${ }^{90}$, oculta su gracia ${ }^{91}$ de los asuntos de sus alrededores. Nos dio la bienvenida su gente, allanó para nosotros su vastedad y su llanura ${ }^{92} \mathrm{y}$ siguió con nosotros el ejemplo del jeque su joven y su adulto. Cuando amanecimos nos apresuramos a su populoso campamento y elogiamos, pues al jeque se le elogia por su gente. Observamos jaimas y poblados, lo nuevo y lo ruinoso, echaderos y descansaderos de ganado ${ }^{93}$, lugares de reunión y moradas, y un hogar que se conoce

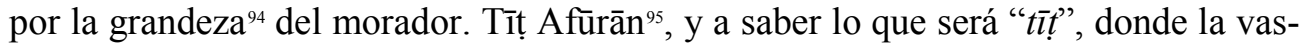
ta extensión, el forraje y la pradera, el río circundante, en la que estalló para el agua dulce una fuente, como la plata fluye, o como bruñe la hoja de la espada un herrero. Ha ocupado la cima ${ }^{96}$ de sus casas un alcázar erigido del que se alarga un cuello y en el que se ha promovido el control y la consolidación ${ }^{97}$. Dan vueltas [sobre él] las casas como teje la araña, se dirigen hacia él los caminos y las direcciones, se alborota ante él el zoco ${ }^{98}$, y se hace patente en el orgullo de su habitante la superioridad. Y dije:

[p. 92] Hicimos parada en el campamento de los nobles Jult,

en la hermana de La Caaba y La Meca. ${ }^{99}$

Y quien es de los invitados de Abū Kațīr,

prescinde con los actos de las palabras.

${ }^{87} \mathrm{El}$ "țarīd" o "tarīda" se prepara con trozos de pan migados en un caldo grasiento, y la "harīra" es una sopa espesa con especias que se puede preparar de diversas maneras (GARCÍA SÁNCHEZ, Expiración, "La alimentación popular urbana en al-Andalus", en Arqueología medieval, 4 (1996) 225).

${ }^{88}$ Esta parte entre corchetes falta en el manuscrito de la Nufäda y la ha completado la editora de la versión de la Rayḥ̄ana.

${ }^{89}$ Según 'Azzāwī, esta al-Zāwiya es distinta a la anterior que estaba en las tierras de Sufyān. Esta está en Tịt Afūrān o en sus alrederores ('AZZĀWĪ, Rahalāt, 83).

${ }^{90}$ Probablemente se refiera a que no la había alcanzado la peste.

${ }^{91}$ La palabra es confusa en el manuscrito y las propuestas de los editores también. Se propone "milhahu", que también podría ser "su sal".

${ }^{92}$ Lo que viene a significar el conocido "ahlan wa-sahlan" en el sentido de dar la bienvenida.

${ }^{93}$ Lugares de descanso del ganado tras abrevar.

${ }^{94}$ Se ha traducido la variante de la Rayḥāna: "bi-așāla" por tener más sentido que la de la Nufāọa cuya traducción sería "un hogar que conoce la aflicción (iṣāba) del morador".

${ }^{95}$ Según Fāgiya, probablemente se corresponda con la actual Afūrār, y "tît " es una palabra beréber que significa "manantial". Era donde se encontraban dos caminos: el de al-ŷihād, que fue el tomado por Ibn al-Jațīb, y el del cobre (MIFTĀḤ, Muhammad, "Ba ḍ̣ Maẓāhit Tāmasnā min jilāl riḥla", en AlŠâwiya: al-tārīj wa-l-mầāl, (1997), 146-7).

${ }^{96}$ Sustituido y traducido como "dirwa" siguiendo la variante de la Rayhāna por no encontrar sentido a la de la Nufäda.

${ }^{97}$ Probablemente se refiera a que el alcázar tenía una torre y que su construcción era sólida.

${ }^{98}$ Según 'Azzāwī, debía ser una zona de importancia comercial por su emplazamiento conectando la montaña con el llano y siendo una etapa en el paso de las caravanas de Fez a Marraquech



${ }^{99}$ Compara el autor Tit Afūrān con La Caaba (al-rukn) y La Meca (al-balad al-harām). 
Ciertamente sus casas son como oímos, casas de caballería y de grandes favores.

Las protegen los jinetes en las alturas,

y las alfombran los esclavos jóvenes ${ }^{100}$ con comida. ${ }^{101}$

Independientemente del contexto de este inacabado relato y de los móviles que su autor tuvo o no para realizar el viaje en él descrito, pues al fin y al cabo este estudio no es más que una interpretación posible de lo que sucedió que nunca pretende ofrecer una verdad inalcanzable, resulta innegable la exquisitez de su visión. La visión del visir de la gran urbe andalusí experimentando en su exilio la realidad tribal magrebí. Su prosa epistolar puede resultar recargada pero sus bosquejos literarios de lo que contemplaba están llenos de vida. Ibn al-Jațīb ve el mundo a través de imágenes retóricas. Unas espontáneas, otras laboriosamente fabricadas. Obviamente recurre a tópicos, y lo hace a menudo. Pero hay momentos en el relato en los que sólo él parece capaz de dibujar el cuadro con unos giros metafóricos que activan el intelecto unas veces y otras transmiten puro sentimiento.

Este tiempo que pasó Ibn al-Jațīb exiliado en el Magreb, aunque agitado, dejó una gran impresión en su persona. Tal fue su apego y su añoranza a aquellas tierras que los dejó plasmados en su autobiografía salpicados de la vanidad y el orgullo que le eran propios:

Me dijeron: ¿Hasta cuándo llorarás Fez?

Y dije: la fidelidad no se reprocha.

Si yo no me apeno por un tiempo pasado, y por una época que pasó en una brisa y se degustó, pues que no componga mi ingenio la perla de la poesía, ni sea la literatura la mayor de mis ocupaciones. ${ }^{102}$

\footnotetext{
${ }^{100}$ Se refiere a los nacidos esclavos.

${ }^{101}$ El relato termina aquí, y es hasta donde llega el texto que incluyó Ibn al-Jațīb en la Rayḥāna.

${ }^{102}$ IBN AL-JAṬīB, Ihạtạ, vol. IV, 496.
} 


\section{ANEXO}



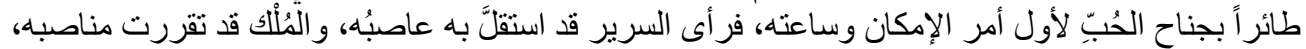

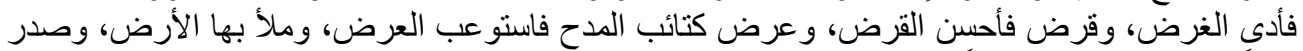

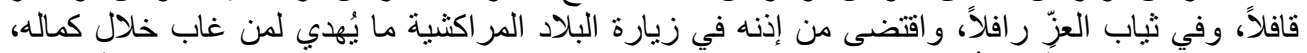



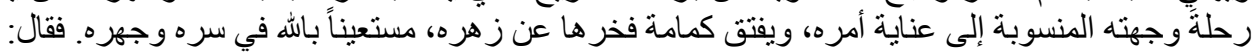

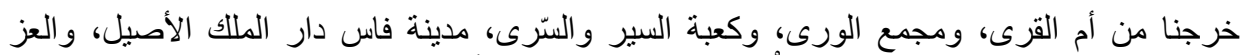

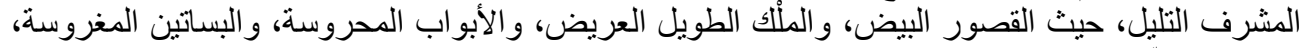





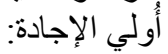

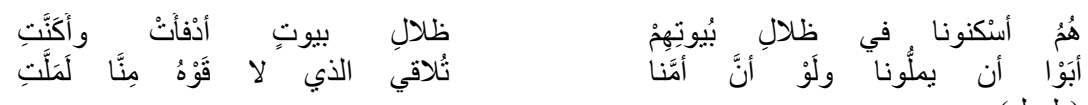



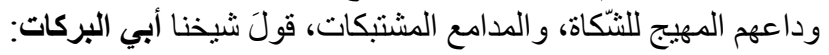

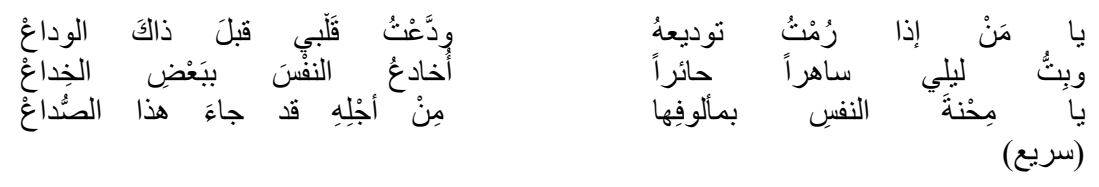

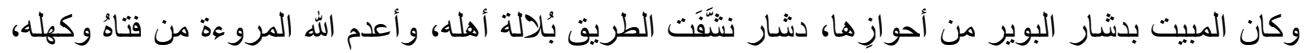

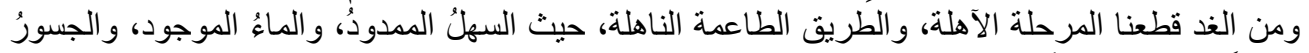
المحنيَّة، والدشور السنَّيَّة والآثار المرينية، إلى مدينة مِكناسة.

$$
\text { ومنها بعد كثير. }
$$

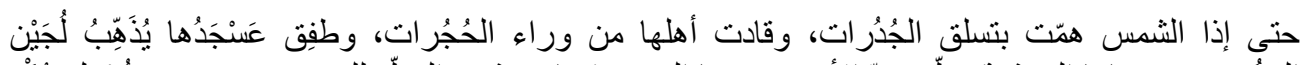



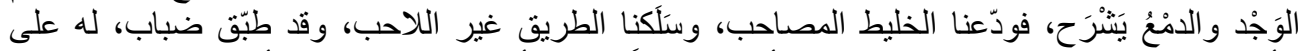

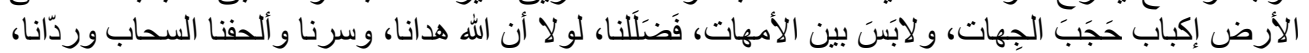

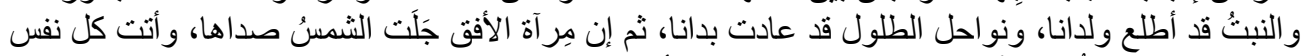

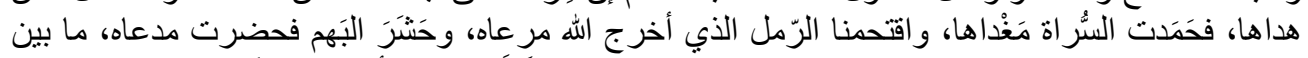



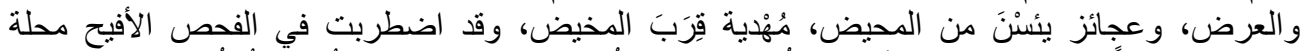

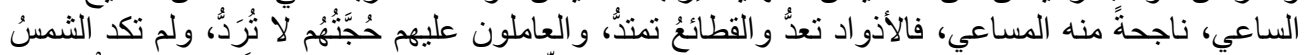

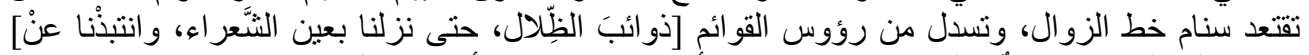

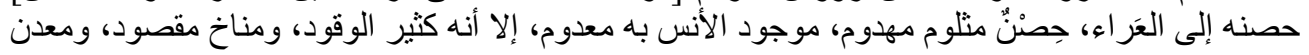




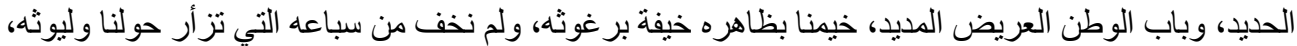

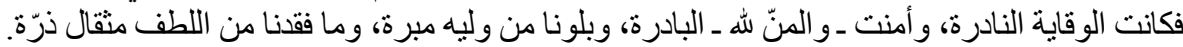

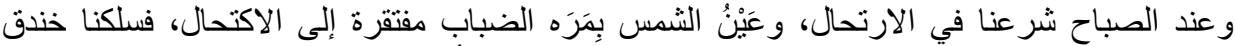

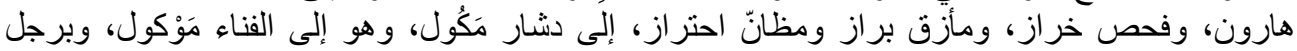

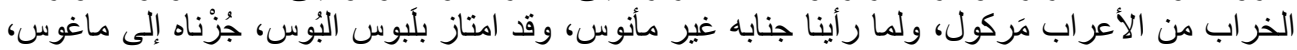

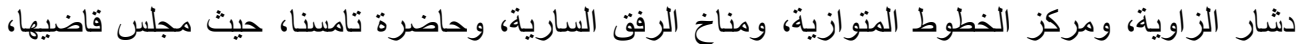

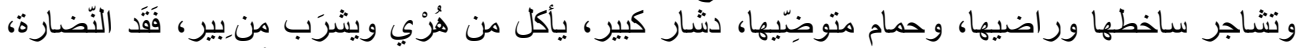



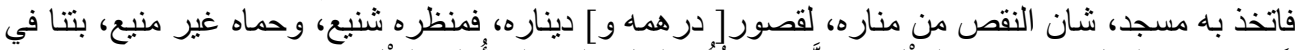


و أنشدته من الغد: الغدل:

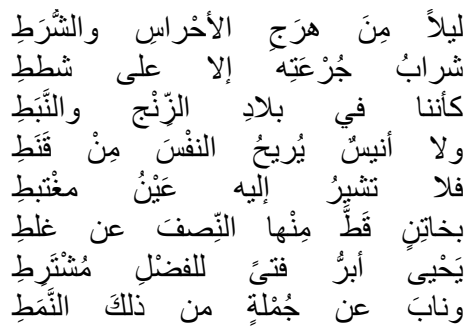



(بسيط)

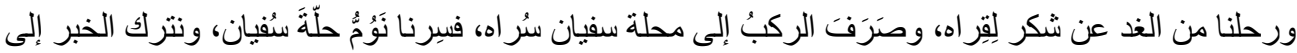

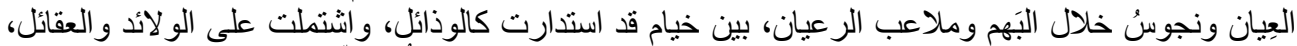



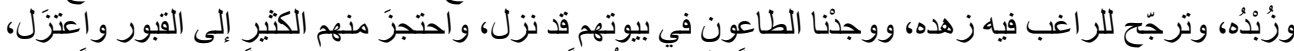



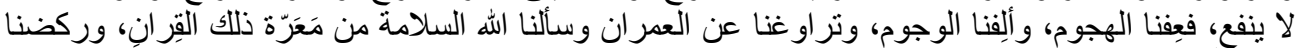

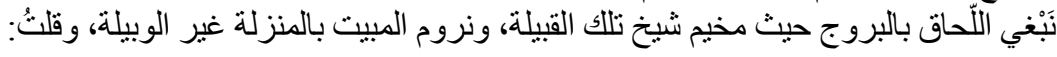



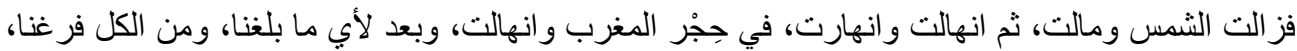

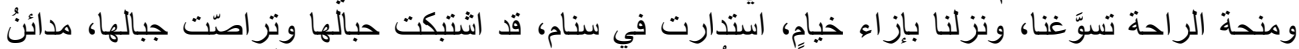

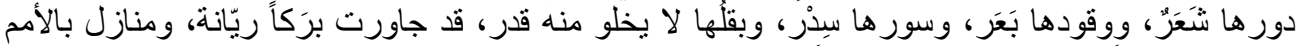

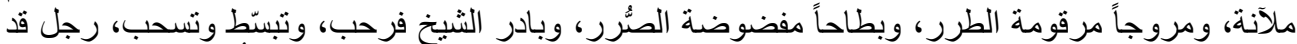

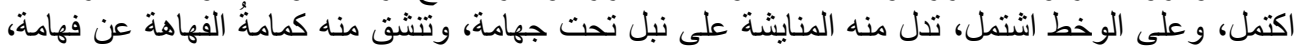

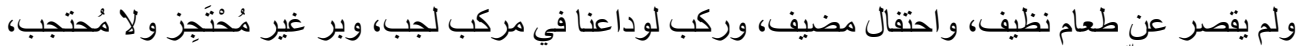

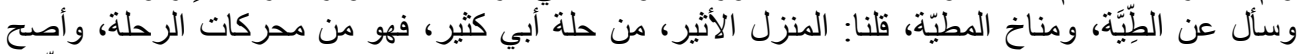

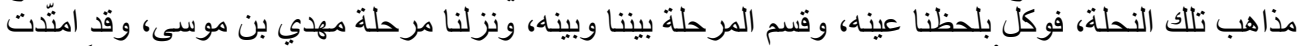

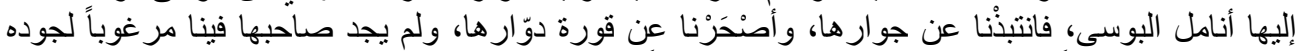

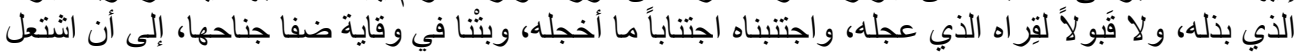


في فحمة الليل صباحها، فركضنا تحت رواق ضباب ساتر ، ورذاذ له مستأثر ، لم تزل الثمس ترشقاه، و الرياح

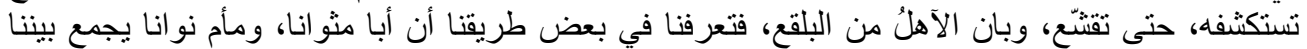

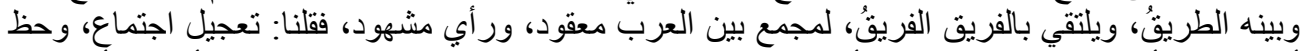

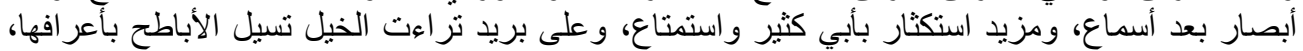

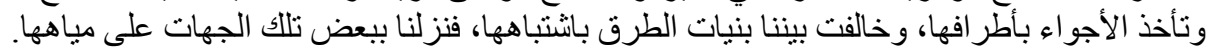

و خاطبته بما نصسه:
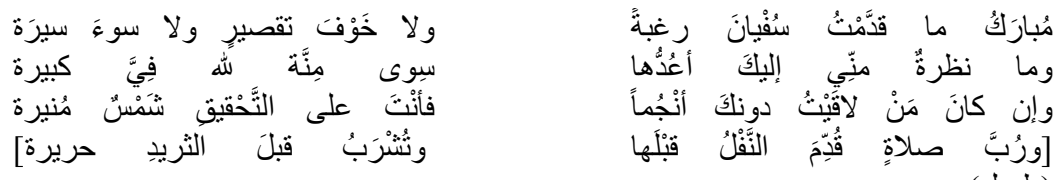

(طويل)

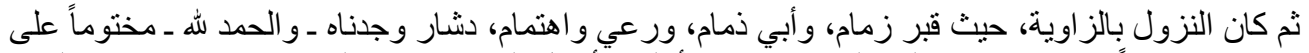





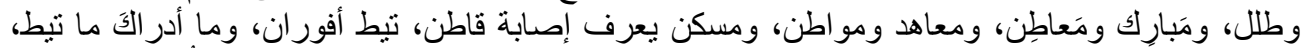

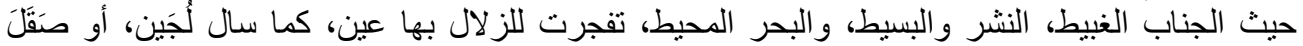



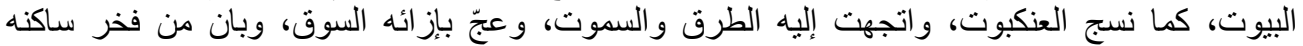
البسوق. وقلت:

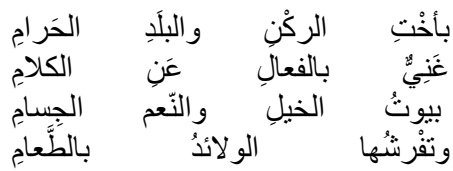

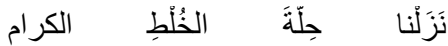

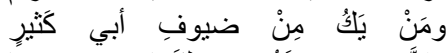

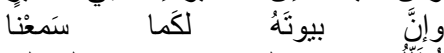

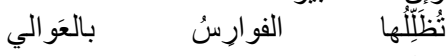

